\title{
Implementasi Manajemen Sekolah untuk Meningkatkan Mutu Pendidikan di Tingkat Sekolah Menengah Pertama (SMP)
}

\author{
Efriani ${ }^{1}$, Nur Ahyani ${ }^{2}$, Ahmad Hussein Fattah ${ }^{3^{*}}$ \\ ${ }^{1}$ SMP Negeri 1 Abab Pali \\ ${ }^{2}$ Program Pasca Sarjana Universitas PGRI Palembang \\ 'Universitas Muhammadiyah Palembang \\ Jl. Jendral A Yani No 13 Ulu Kota Palembang 30263 Sumatera Selatan \\ *Email: ahusseinfattah@yahoo.com
}

Naskah diterima 10 Agustus 2021, Revisi 15 September 2021, Terbit 29 Oktober 2021

\begin{abstract}
DOI: doi.org/10.21107/pamator.v14i2.11533
Abstract

The purpose of this study was to find out how to describe the implementation of school-based management (SBM), how to improve the quality of education through school-based management, as well as the supporting and inhibiting factors in the implementation of school-based management. This study uses a qualitative approach with a descriptive method. Data collection techniques in this study are interview techniques, observation techniques and document study techniques. The subjects and informants in this study were the principal, vice principal, head of administrative officer, and the community. The data obtained in the field were analyzed by means of data reduction, data presentation and finally conclusions. The results obtained: (1) The implementation of school-based management at SMP Negeri 4 Abab can be said to be running well. (2) In the process of implementing SBM at SMP Negeri 4 Abab, namely the first input at this stage the principal makes a program implementation plan through deliberation involving all interest groups. The second stage of the process, in this stage the implementation of what was previously planned. Finally, the output or result of the SBM implementation process is to produce students with high achievements and to improve the quality of education. (3) The supporting factor in implementing SBM in SMP Negeri 4 Abab is that there is support from teachers, administrative officer and the community, both in the form of personnel and financial support. While the inhibiting factors are the people who are indifferent, lack of funds and inadequate facilities and infrastructure.
\end{abstract}

Key words: school-based management, quality of education, qualitative approach

\section{PENDAHULUAN}

Peran serta masyarakat dalam menyukseskan pendidikan, sejalan dengan UU No.20 tahun 2003 tentang Sistem Pendidikan Nasional. Pada Bab 1, Pasal 1 ayat 16 dijelaskan bahwa: "Pendidikan berbasis masyarakat adalah merupakan penyelenggaraan pendidikan berdasarkan kekhasan agama, sosial, budaya, aspirasi dan potensi masyarakat sebagai perwujudan pendidikan dari, oleh dan untuk masyarakat". Artinya, peran penting masyarakat sangat perlu dalam membantu mensuksekan tujuan pendidikan di Indonesia. Pada dasarnya masyarakatlah yang tahu akan kebutuhan yang harus dipenuhi, sehingga masyarakat memiliki tanggung jawab terhadap peningkatan kualitas pendidikan.

Berbagai upaya telah dilakukan pemerintah untuk meningkatkan mutu pendidikan nasional. Salah satunya adalah dengan penerapan Mutu Berbasis Sekolah (MBS) yang dalam prakteknya lebih dikenal sebagai Manajemen Peningkatan Mutu Berbasis Sekolah (MPMBS). Secara umum, MPMBS diartikan sebagai model manajemen yang memberi otonomi yang lebih besar kepada sekolah dan mendorong pengambilan keputusan partisipatif yang melibatkan secara langsung semua anggota sekolah untuk meningkatkan mutu sekolah berdasarkan kebijakan pendidikan nasional.

Manajemen Peningkatan Mutu Berbasis Sekolah (MPMBS) akhir-akhir ini kembali giat diperkenalkan. Hal ini dapat diartikan bahwa pemberian otonomi yang lebih luas kepada sekolah dapat mendorong pengambilan keputusan partisifatif. Keputusan partisipatif melibatkan semua warga sekolah di antaranya: kepala sekolah, guru, murid, wali murid, masyarakat atau siapa saja yang mempunyai perhatian terhadap pendidikan. 
Otonomi sekolah memberikan wewenag yang besar dalam mengelola sekolah, sehingga sekolah akan lebih mandiri. Dengan mandirinya sekolah, diharapkan sekolah dapat mengembangkan programprogram yang sesuai dengan kebutuhan dan potensi yang dimiliki (Rivai dan Murni, 2010). Sehubungan dengan deskripsi di atas bahwa manajemen berbasis sekolah adalah salah satu kebijakan dan upaya pemerintah untuk mencapai keunggulan masyarakat bangsa dalam penguasaan ilmu dan teknologi, diharapkan dapat dijadikan landasan dalam pengembangan pendidikan di Indonesia yang berkualitas dan berkelanjutan.

Kehadiran MBS diharapkan dapat menyelesaikan permasalahan sistem pendidikan pendidikan yang telah ada, sebelumnya sekolah diwajibkan mengikuti sistem pendidikan terpusat/ sentralisasi. Hal ini menyebabkan ketidakselarasan antara sistem pendidikan dengan tuntutan ataupun kebutuhan yang diperlukan masyarakat. Penerapan MBS menjadikan sekolah lebih mandiri dan dapat mengembangkan sekolah berdasarkan program pendidikan yang sesuai dengan potensi dan kebutuhan masyarakat di sekitarnya.

Manajemen berbasis sekolah merupakan kebijakan pemerintah dalam upaya untuk memajukan masyarakat dan bangsa dalam bidang pendidikan dan teknologi, sehingga pendidikan di Indonesia dapat berkembang dan berkelanjutan dalam upaya peningkatan sumber daya manusia. Secara umum, tujuan penerapan MBS adalah peningkatan mutu pendidikan yang berkelanjutan. Peningkatan mutu tersebut dilakukan secara bertahap dengan target yang terukur melalui tata kelola sekolah yang baik. Rusman (2012) menjelaskan bahwa, secara umum mutu mengandung makna tingkat keunggulan suatu produk baik berupa barang atau jasa, baik yang tangible maupun intangible. Sedangkan dalam konteks pendidikan, pengertian mutu adalah mengacu pada proses pendidikan yang mencakup input, seperti bahan ajar, metodologi, sarana sekolah, dukungan administrasi sarana prasarana, sumber daya lainnya serta penciptaan suasana yang kondusif. Oleh karena itu, mutu pendidikan mengandung makna kemampuan sumber daya sekolah dalam mentransformasikan berbagai jenis masukan dan situasi pencapaian derajat nilai tambah tertentu bagi peserta didik. Termasuk dalam rangka mutu proses pendidikan ini adalah derajat kesehatan, keamanan, disiplin, keakraban, saling menghormati, kepuasan dan lain-lain dari objek selama memberikan dan menerima jasa layanan.

Menurut Jalal dan Supardi (2011) ada beberapa faktor yang menyebabkan rendahnya mutu pendidikan diantaranya: rendahnya kualitas guru, manajemen dan kepemimpinan sekolah, relevansi hokum dengan perkembangan zaman, serta sarana dan prasarana sekolah yang kurang memadai dan lain-lain. Perlu disadari bahwa kesenjangan mutu pendidikan dapat saja terjadi karena penerapan pendekatannya belum terlaksana maksimal antara pihak sekolah dengan masyarakat, baik yang berhubungan dengan manajemen sekolah, dan kepedulian masyarakat terhadap pendidikan yang sangat rendah.

Rendahnya peran serta masyarakat dalam menentukan kebijakan sekolah dikarenakan masyarakat kurang merasa memiliki, kurangnya tanggung jawab dalam memelihara dan membina sekolah tempat anaknya bersekolah.Padahal pendidikan adalah tanggung jawab bersama antara pemerintah, orang tua, dan masyarakat. Tanpa adanya dukungan dari masyarakat pendidikan tidak akan berhasil maksimal, dan apabila dikaji lebih lanjut beberapa komponen penentu peningkatan mutu sekolah antara lain adalah manajemen pemberdayaan masyarakat.

Sebuah sekolah dapat dikatakan bermutu jika sistem manajemen pendidikan yang kompleks dapat berjalan dengan baik. Komponen manajemen tersebut meliputi : (1) manajemen administrasi; (2) manajemen peserta didik; (3) manajemen tenaga pendidik dan tenaga kependidikan; (4) manajemen keuangan; (5) manajemen sarana dan prasarana; (6) manajemen kurikulum dan (6) manajemen humas. Jika komponen tersebut dilaksanakan dengan terorganisir dan terkordinasi secara dinamis, bersinergi, loyalitas tinggi dan mampu bekerja sama dan bertangung jawab terhadap apa yang dikerjakan, maka sekolah tersebut dianggap telah berhasil menerapkan manajemen berbasis sekolah. 


\section{METODOLOGI}

Metode yang digunakan dalam penelitian ini adalah metode deskriptif kualitatif. Teknik pengumpulan data berupa observasi, wawancara dan dokumentasi. Teknik analisis data kualitatif meliputi tiga unsur alur kegiatan sebagai sesuatu yang terjadi pada saat sebelum, selama, dan sesudah pengumpulan data dalam bentuk sejajar untuk membangun suatu analisis, yaitu pengumpulan data, reduksi data, penyajian data, dan penarikan kesimpulan/ verifikasi (Miles dan Huberman, 2012). Proses wawancara kepada pihak sekolah SMP Negeri 4 Abab serta observasi/ studi dokumen dilakukan mulai pada tanggal 1 Februari 2021 hingga tanggal 1 Maret 2021.

\section{HASIL PEMBAHASAN}

Proses Implementasi Manajemen Berbasis Sekolah

Proses implementasi merupakan serangkaian urutan pelaksanaan yang tersusun secara sistematis, adapun urutan proses implemetasi tersebut dimulai dari adanya masukan (input), proses dan hasil (output). Berdasarkan beberapa temuan yang peneliti dapatkan, bahwa proses implementasi manajemen berbasis sekolah di SMP Negeri 4 Abab sudah berjalan dengan baik. Hal itu dapat dilihat dari temuan-temuan yang peneliti dapatkan yang pertama pada tahap input (masukan), kepala sekolah selalu melakukan rapat dengan bawahannya, kemudian melakukan musyawarah dengan wali siswa tiap semesternya dan menerima segala kritik, saran dan masukan yang membangun dari sekolah. Kedua yaitu tahap proses, kepala sekolah melaksanakan apa yang menjadi saran dan masukan dari anggotanya maupun masyarakat, pelaksanaan tersebut tidak terlepas dari pengawasan kepala sekolah dan tak terlepas pula dari peran serta masyarakat karena telah banyak memebrikan sumbangsih berupa tenaga maupun uang. Ketiga yaitu tahap hasil yang didapat adalah menambah keharmonisan hubungan sekolah dengan masyarakat, kemudian siswa menghasilkan prestasi diberbagai bidang sehingga mutu pendidikan di sekolah ini meningkat.

Upaya dalam Meningkatkan Mutu Pendidikan Upaya dalam meningkatkan mutu pendidikan adalah sesuatu yang biasa dilakukan oleh kepala sekolah. Berdasarkan beberapa temuan yang peneliti temukan dapat disimpulkan bahwa upaya kepala sekolah dalam meningkatkan mutu pendidikan di SMP Negeri 4 Abab diantaranya adalah: (1) menjaga kualitas layanan terhadap masyarakat dengan menerima kritik dan saran dari masyarakat dan wali siswa; (2) mengawasi pelaksanaan program kegiatan; (3) melalukan perbaikan terus menerus; (4) membuat kebijakan kebijakan, seperti kedisiplinan dalam kehadiran dan berpakaian; (5) memberlakukan sistem reward and punishment dan (6) menjaga hubungan baik antara sekolah dengan masyarakat.

\section{Faktor Pendukung dan Penghambat}

Faktor pendukung dalam implementasi MBS di SMP Negeri 4 Abab adalah adanya dukungan masyarakat yang sangat kuat, seperti keikutsertaan dalam membantu menjaga keamanan sekolah, membantu dalam berbagai penyelengaraan kegiatan sekolah dan memberikan berbagai masukanmasukan, ide kreatif yang dapat memajukan sekolah. Ada juga yang membantu untuk mempersiapkan kebutuhan perlombaan yang diikuti sekolah.

Kemudian faktor penghambat dalam implementasi manajemen berbasis sekolah dalam meingkatkan mutu pendidikan di SMP Negeri 4 Abab, adapun faktor penghambat dalam implementasi manajemen berbasis sekolah di sekolah ini yaitu: terdapat beberapa pihak yang kurang mendukung peraturan yang terapkan di sekolah ini, sebagian masyarakakat ada yang tidak suka dengan sekolah ini dan tidak mau membantu untuk kemajuan sekolah. Faktor penghambat lainnya yaitu, sekolah ini kekurangan dana sehingga sarana dan prasarana kurang memadai. Selain itu sumber daya manusia juga kurang memadai, pihak sekolah sangat sulit menemukan guru untuk melatih ekstrakurikuler yang telah direncanakan, sehingga banyak ekstrakurikuler yang terbengkalai begitu saja.

\section{Implementasi Manajemen Berbasis Sekolah}

Dalam rangka Implementasi manajemen berbasis sekolah, fungsi - fungsi sekolah yang awalnya dikerjakan oleh pemerintah sebagian di-desentralisasikan kepada sekolah untuk dijalankan secara profesional. 
Hal tersebut berarti terdapat fungsi-fungsi tertentu yang tidak dapat dilimpahkan kepada sekolah sepenuhnya, sebagian masih merupakan porsi kewenangan pemerintah pusat, dinas pendidikan provinsi, dinas pendidikan kota/kabupaten. Adapun fungsifungsi yang sebagian porsinya digarap oleh sekolah dalam kerangka manajemen berbasis sekolah meliputi: (1) proses belajar mengajar, (2) perencanaan dan evaluasi program sekolah, (3) pengelolaan kurikulum, (4) pengelolan ketenagaan, (5) pengelolan peralatan dan perlengkapan, (6) pengelolaan keuangan, (7) pelayanan peserta didik, (8) hubungan sekolah masyarakat, dan (9) pengelolaan iklim sekolah (Wibowo, 2013). Berdasarkan analisis peneliti, bahwasa SMP Negeri 4 Abab telah mampu menjalankan MBS dilihat dari tahapan proses penerapannya. Sekolah telah memberlakukan pengambilan keputusan yang partisipasif melalui pengambilan keputusan dalam musyawarah yang melibatkan semua kelompok kepentingan dari mulai guru dan staf pegawai sampai masyarakat dan orang tua siswa. Suara terbanyak akan menjadi keputusan akhir.

Melihat dari proses implementasi MBS yang dilakukan di SMP Negeri 4 Abab diatas, dimulai dari input, proses dan outputnya, sekolah ini telah mampu melibatkan masyarakat dalam proses perencanaan dan membuat visi dan misi sesuai kebutuhan masyarakat. Kepala sekolah sudah mengelola program dengan pengelolaan yang bersifat lentur (fleksibel), serta mengawasi pelaksanaan program secara teratur. Hasil dari proses itu yaitu, sekolah ini mengahsilkan output berupa prestasi yang membanggakan. Maka sekolah ini dapat dikatakan telah berhasil dalam proses implementasi manajemen berbasis sekolah.

\section{KESIMPULAN}

Berdasarkan uraian hasil dan pembahasan dapat disimpulkan bahwa implementasi manajemen berbasis sekolah di SMP Negeri 4 Abab dapat dikatakan berjalan dengan baik. Selain itu sekolah ini memiliki manajemen humas yang sangat baik dengan masyarakat setempat, peran serta masyarakat sangat tinggi, antara pihak sekolah dan masyarakat sudah sangat akrab bagaikan keluarga yang saling membantu sama lain, masyarakat setempat bahkan rela membantu bergantung royong untuk membersihkan lingkungan sekolah. Pada proses implementasi MBS di SMP Negeri 4 Abab yaitu Pertama, input pada tahap ini kepala sekolah membuat perencanaan pelaksanaan program melalui musyawarah dnegan melibatkan seluruh kelompok kepentingan dari mulai tenaga pendidik dan kependidikan, orang tua siswa dan masyarakat. Kedua tahap proses, dalam tahap ini dilakukan penerapan dari apa yang direncanakan sebelumnya, kemudian pelaksanaan tersebut tidak terlepas dari pengawasan kepala sekolah agar prosesnya berjalan dengan baik serta adanya evaluasi, tak lupa pula untuk tahap proses ini kepala sekolah tetap melibatkan masyarakat sebagai salah satu sumber daya sekolah. Kemudian yang terakhir adalah output atau hasil dari proses implementasi MBS tersebut adalah menghasilkan siswa yang berprsetasi serta peningkatan mutu pendidikan tercapai.

Faktor pendukung dalam penerapan MBS di SMP Negeri 4 Abab ialah terdapat adanya dukungan dari masyarakat baik dukungan berupa tenaga maupun finansial, dukungan dari guru dan staf pegawai yang mampu bekerja sama dengan baik dengan meningkatkan mutu sekolah. Sedangkan faktor penghambat seperti kurang dukungan dari masyarakat yang tak peduli. Kemudian kurangnya dana yang mengakibatkan beberapa program-program ektrakurikuler untuk siswa terhambat kurangnya sarana dan prasarana yang diakibatkan oleh dana yang tidak memadai, sehingga tidak memenuhi standar sarana dan prasarana tingkat SMP.

\section{DAFTAR PUSTAKA}

Dharma, Agus. 2013. Manajemen Supervisi: Petunjuk Praktis Bagi Para Supervisor. Jakarta: Raja Grafindo Persada.

Depdiknas .2003.Undang-undang RI No.20 tahun 2013.tentang Sistem Pendidikan Nasional.

Jalal, Fasli dan Dedi Supriadi. 2011. Reformasi Pendidikan Dalam Konteks Otonomi Daerah. Yogyakarta: Adicita Karya Nusa. 
Kemendikbud. 2014. Konsep dan Implementasi Kurikulum 2013. Jakarta: Kementrian Pendidikan dan Kebudayaan.

Miles dan Huberman.2012. Analisis Data Kualitatif Terjemahan Oleh Tjetjeb Rohendi Rohandi. Jakarta: Universitas Indonesia.

Mulyasa, E. 2013. Managemen Berbasis Sekolah. Bandung : Penerbit PT Remaja Rosdakarya.

Mulyasa, E. 2010.Menjadi Guru Profesional Menciptakan Pembelajaran Kreatif dan Menyenangkan. Bandung: Penerbit PT Remaja Rosdakarya.

Mulyasa, E. 2014.Manajemen Berbasis Sekolah: Konsep, Strategi dan Implementasi. Bandung: Penerbit PT Remaja Rosdakarya.

Nurkholis. 2013. Manajemen berbasis sekolah: Teori, Model dan Aplikasinya. Jakarta: Grasindo.

Rivai, Veithzal dan Sylviana Murni. 2009. Education Management. Jakarta.

Rusdiana, H. A, 2014. Konsep Inovasi Pendidikan. Bandung: Pustaka Setia.
Rusman, 2012.Model-model Pembelajaran: Mengembangkan Profesionalisme Guru. Raja Grafindo Persada, Jakarta

Sunanto 2015. Implementasi Manajemen Berbasis Sekolah dalam Peningkatan Mutu Pendidikan pada SMPN 19 Percontoha Banda Aceh.Jurnal Mahasiswa PPS Universitas Syeh Kuala. Volume 3 Nomor 1: 51-52

Tim Dosen. 2013. Pengantar Dasar Pendidikan .FIP IKIP Malang. Malang: Usaha Nasional.

Undang-Undang Nomor 20 Tahun 2013 Tentang Sistem Pendidikan Nasional.

Wibowo, Agus. 2013. Manajemen Pendidikan Karakter di Sekolah. Yogyakarta: Pustaka Belajar. 